\title{
MANAJEMEN PESETA DIDIK
}

\author{
Hamidah D, M.Pd
}

STKIP Budidaya Binjai

\begin{abstract}
Abstrak
Peserta didik dalam pemaknaan regulasi kependidikan adalah anggota masyarakat yang berusaha mengembangkan potensi diri melalui proses pembelajaran yang tersedia pada jalur, jenjang, dan jenis pendidikan tertentu. Manajemen peserta didik merupakan bagian penting yang harus diperhatikan dalam penyelenggaraan kegiatan pendidikan di sekolah. Program-program kegiatan manajemen kepeserta didikan yang diselenggarakan harus didasarkan kepada kepentingan dan perkembangan dan peningkatan kemampuan peserta didik dalam bidang kognitif, afektif dan psikomotor dan sesuai dengan keinginan, bakat dan minat peserta didik. Pengadaan program kegiatan manajemen kepeserta didikan diharapkan dapat menghasilkan keluaran yang bermutu.
\end{abstract}

Kata Kunci: Manajemen, Peserta Didik

\section{PENDAHULUAN}

Keberhasilan dalam penyelanggaraan lembaga pendidikan (sekolah) akan sangat bergantung kepada manajemen komponen-komponen pendukung pelaksanaan kegiatan seperti kurikulum, peserta didik, pembiayaan, tenaga pelaksana, dan sarana prasarana. Komponen-komponen tersebut merupakan satu kesatuan dalam upaya pencapaian tujuan lembaga pendidikan (sekolah), artinya bahwa satu komponen tidak lebih penting dari komponen lainnya. Akan tetapi satu komponen memberikan dukungan bagi komponen lainnya sehingga memberikan kontribusi yang tinggi terhadap pencapaian tujuan lembaga pendidikan (sekolah) tersebut komponen peserta didik, sosial keberadaannya sangat dibutuhkan, terlebih bahwa pelaksanaan kegiatan pendidikan di sekolah, peserta didik merupakan subyek sekaligus obyek dalam proses transformasi ilmu pengetahuan dan keterampilan-keterampilan yang diperlukan. Oleh karena itu keberadaan peserta didik tidak hanya sekedar memenuhi kebutuhan saja, akan tetapi harus merupakan bagian dari kebermutuan dari lembaga pendidikan (sekolah). Artinya bahwa dibutuhkan manajemen peserta didik yang bermutu bagi lembaga pendidikan (sekolah) itu sendiri. Sehingga peserta didik itu dapat tumbuh dan berkembang sesuai dengan potensi fisik, kecerdasan intelektual, emosional, dan kejiwaan peserta 
didik. Kebutuhan peserta didik dalam mengembangakan dirinya tentu saja beragam dalam hal pemrioritasan, seperti disatu sisi para peserta didik ingin sukses dalam hal prestasi akademiknya, disisi lan ia juga ingin sukses dalam hal sosialisasi dengan teman sebayanya. Bahkan ada juga peserta didik yang ingi sukses dalam segala hal. Pilihan-pilihan yang tepat atas beragaman keinginan tersebut tidak jarang menimbulkan masalah bagi para peserta didik. Oleh karena itu diperlukan layanan bagi peserta didik yang dikelola dengan baik. Manajemen peserta didik berupaya mengisi kebutuhan akan layanan yang baik tersebut, mulai dari peserta didik tersebut mendaftarkan diri ke sekolah sampai peserta didik tersebut menyelesaikan studi di sekolah tersebut.Peserta didik merupakan unsur inti kegiatan pendidikan. Karena itu, jika tidak ada peserta didik, tentunya tidak akan ada kegiatan pendidikan. Lebih- lebih di era persaingan antar lembaga pendidikan yang begitu ketat seperti sekarang, sekolah harus berjuang secara sungguh-sungguh untuk mendapatkan peserta didik. Tak sedikit lembaga pendidikan yang mati karena kehabisan peserta didik. Bahkan ada ketua yayasan pendidikan yang mencari guru baru. Dikatakannya, untuk mendapatkan guru baru cukup membuka lamaran, sehari sudah banyak yang datang. Sedangkan untuk mencari peserta didik, belum tentu dengan mendengarkan brosur dan memasang spanduk peserta didik akan datang. Hal ini menggambarkan bahwa dalam kegiatan pendidikan di era persaingan ini, peserta didik merupakan unsur utama yang harus di manage dan dihargai martabatnya tak jauh berbeda dengan pembeli/konsumen dalam dunia usaha.

Manajemen peserta didik berasal dari gabungan kata "manaejemen" dan "peserta didik". Dalam makna bahasa, manajemen berarti ketalaksanaan dan tata pimpinan. Selain itu manajemen juga berarti kepemimpinan terhadap suatu kelompok guna mencapai tujuan. Sedangkan dalam makna teoritik, manajemen berarti ilmu atau seni mengatur pemanfaatan sumber daya manusia (SDM) dan sumber daya lain secara efektif dan efisien untuk mencapai tujuan tertentu (Adair, 1993: 4).

Secara etimologis, kata manajemen merupakan terjemahan dari kata management (Bahasa Inggris). Kata management sendiri berasal dari kata manage atau magiare yang berarti melatih kuda dalam melangkahkan kakinya. 
Dalam pengertian manajemen, terkandung dua kegiatan, yaknikegiatan pikir (mind) dan kegiatan tindak laku ( action).

Robbin dan Coulter dalam Saefullah (2012:2) menjelaskan manajemen menurut istilah adalah proses mengordinasikan aktivitas-aktivitas kerja sehingga dapat selesai secara efisien dan efektif dengan dan melalui orang lain.

Dalam Encylopedia Of The Social Science dikatakan bahwa manajemen adalah proses pelaksanaan program untuk mencapai tujuan tertentu yang diselenggarakan dan diawasi. Sedangkan Terry Saefullah (2012:3) mengatakan bahwa manajemen merupakan proses khas yang terdiri atas tindakan-tindakan perencanaan, pengorganisasian, penggerakan, dan pegendalian yang dilakukan untuk menentukan serta mencapai sasaran yang telah ditentukan melalui pemanfaatan sumber daya manusia dan sumber daya lainnya.

Lebih luas lagi, Burhanuddin (2004:15) dengan mengutip pendapat Harold Kontz mendefinisikan manjemen sebagai usaha pencapaian tujuan yang diinginkan dengan membangun suatu lingkungan yang kondusif terhadap pekerjaan yang dilakukan oleh dua orang atau lebih dalam sebuah kelompok yang terorganisir. Kegiatan utama manajemen terletak dalam usaha administrator untuk mengatur individu-individu yang terlibat dalam suatu organisasi, sehingga memungkinkan mereka, dapat menyumbangkan tenaga dan pikiran secara maksimal menuju tercapainya tujuan bersama.

Dari beberapa definisi manajemen yang sudah dikemukakan di atas dapat disimpulkan bahwa manajemen adalah ilmu pengetahuan dan seni untuk mengatur, mengoorganisasikan, aktivitas kerja dengan cara memanfaatkan orang lain untuk mencapai suatu tujuan tertentu.

Peserta didik dalam pemaknaan regulasi kependidikan adalah anggota masyarakat yang berusaha mengembangkan potensi diri melalui proses pembelajaran yang tersedia pada jalur, jenjang, dan jenis pendidikan tertentu. Sebutan "peserta didik" tersebut diberikan kepada :

1. Peserta didik pada jenjang pendidikan dasar dengan satuan pendidikan yang meliputi SD, MI atau bentuk lain yang sederajat serta pendidikan dasar lanjutan yang berbentuk SMP dan MTS, atau bentuk lain yang sederajat. 
2. Peserta didik pada jenjang pendidikan menengah, dengan satuan pendidikan yang meliputi SMA, SMK, MA, atau bentuk lain yang sederajat Menurut Arikunto (1986) dalam Mulyasa (2016:18) bahwa peserta didik adalah siapa saja yang terdaftar sebagai objek didik di suatu lembaga pendidikan.Jadi bisa diartikan bahwa peserta didik adalah seseorang yang terdaftar dalam suatu jalur, jenjang, dan jenis lembaga pendidikan tertentu, yang selalu ingin mengembangkan potensi dirinya baik pada aspek akademik maupun non akademik melalui proses pembelajaran yang diselenggarakan.

Dengan menggabungkan dua kata dasar" manajemen" dan "pesertadidik" tersebut, maka" manajemen peserta didik' dapat dirumuskan sebagai penataan dan pengaturan terhadap kegiatan yang berkaitan dengan peserta didik mulai masuk sampai keluarnya pesrta didik tersebut dari suatu lembaga pendidikan(sekolah).

Pengaturan itu dimaksudkan untuk memberikn layanan sebaik-baiknya bagi peserta didik, agar mereka merasa nyaman dan betah mengikuti seluruh program sekolah. Kegiatan penataan tersebut melibatkan seluruh sumber daya, baik sumber daya manusia seperti guru, kepala sekolah, peserta didik itu sendiri, wali murid, maupun sumber daya lain yang meliputi sarana, keuangan, pembelajaran kurikulum, menuju tercapainya tujuan dari penddikan itu sendiri.

Manajemen peserta didik menurut Daryanto (2013:139) meliputi dua bagian, yaitu:

a. Kegiatan di luar kelas, meliputi penerimaan peserta didik, Pencacatan peserta didik, pembagian seragam sekolah penyediaan sarana olahraga dan seni, perpustakaan dan lain- lain.

b. Kegiatan di dalam kelas, meliputi pengeleloaan kelas, interaksi belajar mengajar yang positif, penyediaan media pembelajaran, dan lain- lain.

Di lingkungan sekolah peserta didik itu sangat penting dan diperlukan sekali. Peserta didik merupakan unsur inti kegiatan pendidikan. Karena itu, jika tidak ada peserta didik, tentunya tidak akan ada kegiatan pendidikan. Lebih- lebih di era persaingan antar lembaga pendidikan yang begitu ketat seperti sekarang, sekolah harus berjuang secara sungguh-sungguh untuk mendapatkan peserta didik. Tak sedikit lembaga pendidikan yang mati karena kehabisan peserta didik. Bahkan 
ada ketua yayasan pendidikan yang mencari guru baru. Dikatakannya, untuk mendapatkan guru baru cukup membuka lamaran, sehari sudah banyak yang datang. Sedangkan untuk mencari peserta didik, belum tentu dengan mendengarkan brosur dan memasang spanduk peserta didik akan datang. Hal ini menggambarkan bahwa dalam kegiatan pendidikan di era persaingan ini, peserta didik merupakan unsur utama yang harus di manage dan dihargai martabatnya tak jauh berbeda dengan pembeli/konsumen dalam dunia usaha.

\section{PEMBAHASAN}

\section{Prinsip-Prinsip Manajemen Peseta Didik}

Manajemen kesiswaan atau manajemen peserta didik berfungsi mengatur berbagai kegiatan dalam bidang kesiswaan agar proses pembelajaran di sekolah berjalan dengan tertib, teratur, dan lancar. Untuk mewujudkan tujuan tersebut terdapat sejumlah prinsip yang harus diperhatikan. Prinsip-prinsip tersebut adalah sebagai berikut:

1. Manajemen peserta didik dipandang sebagai bagian dari keseluruhan manajemen sekolah. Oleh karena itu,ia harus mempunyai tujuan yang sama dan mendukung terhadap tujun manajemen secara keseluruhan.

2. Manajemen peserta didik harus mengemban misi pendidikan dan dalam rangka mendidik para peserta didik. Segala bentuk kegiatan,baik itu ringan,berat,disukai atau tidak disukai oleh peserta didik, haruslah diarahkan untuk mendidik peserta didik dan bukan untuk yang lainnya.

3. Kegiatan manajemen peserta didik harus di upayakan untuk mempersatukan peserta didik yang mempunyai aneka ragam latar belakang dan memiliki banyak perbedaan. Perbedaan- perbedaan yang ada pada peserta didik tidak di arahkan bagi munculnya konflik di anatara mereka melainkan justru mempersatukan dan saling memahami.

\section{Ruang Lingkup Manajemen Peserta Didik}

Secara umum manajemen kesiswaan atau manajemen peserta didik sedikitnya memiliki tiga tugas utama yang harus diperhatikan, yaitu penerimaan 
murid baru, kegiatan kemajuan belajar, serta bimbingan dan pembinaan disiplin. Secara rinci, ruang lingkup peserta didik adalah sebagai berikut:

\section{Perencanaan Peserta Didik}

Kegiatan manajemen peserta didik harus diupayakan untuk mempersatukan peserta didik yang mempunyai aneka ragam latar belakang dan memiliki banyak perbedaan. Perbedaan-perbedaan yang ada pada peserta didik tidak diarahkan bagi munculnya konflik diantara mereka melainkan justru mempersatukan dan saling memahami.

Langkah pertama yang harus dilakukan dalam manajemen kesiswaan yaitu mengadakan perencanaan. Peserta didik harus direncanakan, karena dengan adanya perencanaan segala sesuatunya dapat dipikirkan dengan matang. Dengan demikian, masalah-masalah yang muncul akan dapat ditangani sesegera mungkin.

2. Penerimaan Peserta Didik Baru

Penerimaan peserta didik baru adalah salah satu kegiatan manajemen peserta didik yang sangat penting. Dalam penerimaan peserta didik baru ini meliputi beberapa tahapan, yaitu (1) kebijaksanaan penerimaan peserta didik, (2) system penerimaan peserta didik, (3) kriteria penerimaan peserta didik baru, (4) prosedur penerimaan peserta didik baru, dan (5) problema penerimaan peserta didik baru.

\section{Orientasi Peserta Didik}

Peserta didik yang sudah melakukan daftar ulang, mereka kemudian akan memasuki masa orientasi peserta didik di sekolah. Orientasi ini dilakukan dari hari-hari pertama masuk sekolah. Pada bagian ini secara berurutan terdiri dari (1) alasan dan batasan orientasi peserta didik, (2) tujuan dan fungsi orientasi peserta didik, (3) hari-hari pertama di sekolah, (4) pecan orientasi peserta didik.

4. Mengatur Kehadiran Dan Ketidakhadiran Peserta Didik

Kehadiran peserta didik di sekolah sangat penting, karena jika peserta didik tidak hadir di sekolah, tentu aktivitas belajar mengajar di sekolah tidak dapat dilaksanakan. Kehadiran peserta didik di sekolah adalah suatu kondisi yang memungkinkan terjadinya interaksi belajar mengajar. 
5. Pengelompokan Peserta Didik

Peserta didik yang sudah melakukan daftar ulang, mereka perlu dikelompokkan atau diklasifikasikan. Pengklasifikasian diperlukan bukan dimaksudkn untuk mengotak-kotakkan peserta didik, tetapi justru dimaksudkan untuk membantu keberhasilan mereka. Kegiatan yang termasuk dalam bagian ini yaitu (1) urgensi pengelompokan, (2) wacana pengelompokan, (3) jenis-jenis pengelompokan, dan (4) pengelompokan dan penjurusan.

6. Mengatur Evaluasi Hasil Belajar Peserta Didik

Evaluasi hasil belajar terhadap peserta didik sangat perlu dilakukan, agar diketahui perkembangan mereka dari waktu ke waktu. Evaluasi hasil belajar peserta didik dimaksudkan untuk mengetahui sejauh mana peserta didik telah dapat menampilkan performa sesuai yang diharapkan. Kegiatan yang termasuk dalam bagian ini yaitu, (1) alasan perlunya evaluasi hasil belajar peserta didik, (2) batasan evaluasi hasil belajar peserta didik, (4) teknik-teknik evaluasi hasil belajar peserta didik, (5) kriteria-kriteria evaluasi hasil belajar peserta didik, (6) tindak lanjut evaluasi hasil belajar peserta didik.

7. Mengatur Kenaikan Tingkat Peserta Didik

Kenaikan kelas dapat diatur sesuai dengan kebijakan dari msing-masing sekolah. Dalam kenaikan kelas sering terjadi masalah-masalah yang memerlukan penyelesaian secara bijak. Masalah ini dapat diperkecil jika data-data tentang hasil evaluasi siswa obyektif dan mendayagunakan fungsi. Juga para guru harus berhati-hati dalam memberikan nilai hasil evaluasi belajar kepada siswa.

8. Mengatur Peserta Didik Yang Mutasi Dan Drop Out

Mutasi dan drop out seringkali membawa masalah di dunia pendidikan. Oleh karena itu, keduanya harus ditangani dengan baik, agar tidak mengakibatkan keruwetan dan keribetan yang berlarut-larut, sehingga pada akhirnya akan mengganggu aktivitas sekolah secara keseluruhan.

9. Kode Etik, Pengadilan, Hukuman Dan Disiplin Peserta Didik

Pendidikan disini didasarkan atas norma-norma tertentu bagi peserta didik. Norma-norma dan aturan-aturan tersebut, mengharuskan peserta didik untuk mengikutinya. Selain itu, para pendidik selayaknya juga menjadi contoh 
terdepan dalam dalam hal pentaatan terhadap tradisi dan aturan yang dikembangkan di lembaga pendidikan.

\section{Tujuan Dan Fungsi Manajemen Peserta Didik}

Tujuan dari manajemen peserta didik yaitu untuk mengatur kegiatan kegiatan peserta didik agar kegiatan tersebut menunjang proses pembelajaran disekolah agar berjalan lancar, tertib, dan teratur sehingga tercapai tujuan pembelajaran yang efektif dan efisien.

Adapun tujuan manajemen peserta didik secara khusus yaitu sebagai berikut:

1. Meningkatkan pengetahuan, keterampilan dan fsikomotor peserta didik

2. Menyalurkan dan mengembangkan kemampuan umum( kecerdasan) bakat dan minat peserta didik.

3. Menyalurkan aspirasi, harapan dan memenuhi kebutuhan peserta didik.

Fungsi manajemen peserta didik secara umum adalah: sebagai wahana bagi peserta didik untuk mengembangkan diri seoptimal mungkin, baik yang berkenaan dengan segi-segi individualitasnya, segi sosialnya, segi aspirasinya, segi kebutuhannya dan segi-segi potensi peserta didik lainnya.

Fungsi manajemen peserta didik secara khusus dirumuskan sebagai berikut:

1. Fungsi yang berkenaan dengan pengembangan individualitas peserta didik, ialah agar mereka dapat mengembangkan potensi-potensi individualitasnya tanpa banyak terhambat. Potensi-potensi bawaan tersebut meliputi: kemampuan umum (kecerdasan), kemampuan khusus (bakat), dan kemampuan lainnya.

2. Fungsi yang berkenaan dengan pengembangan fungsi sosial peserta didik ialah agar peserta didik dapat mengadakan sosialisasi dengan sebayanya, dengan orang tua dan keluarganya, dengan lingkungan sosial sekolahnya dan lingkungan sosial masyarakatnya. Fungsi ini berkaitan dengan hakekat peserta didik sebagai makhluk sosial.

3. Fungsi yang berkenaan dengan penyaluran aspirasi dan harapan peserta didik, ialah agar peserta didik tersalur hobi, kesenangan dan minatnya. Hobi, kesenangan dan minat peserta didik demikian patut disalurkan, oleh karena ia 
juga dapat menunjang terhadap perkembangan diri peserta didik secara keseluruhan.

4. Fungsi yang berkenaan dengan pemenuhan kebutuhan dan kesejahteraan peserta didik ialah agar peserta didik sejahtera dalam hidupnya. Kesejahteraan demikian sangat penting karena dengan demikian ia akan juga turut memikirkan kesejahteraan sebayanya.

\section{KESIMPULAN}

Berdasarkan pembahasan yang telah kita pelajari di atas maka dapat di ambil kesimpulan bahwa manajemen adalah ilmu pengetahuan dan seni untuk mengatur, mengoordinasikan, aktivitas kerja dengan cara memanfaatkan orang lain untuk mencapai suatu tujuan tertentu. Sedangkan peserta didik adalah seseorang yang terdaftar dalam suatu jalur, jenjang, dan jenis lembaga pendidikan tertentu, yang selalu ingin mengembangkan potensi dirinya baik pada aspek akademik maupun non akademik melalui proses pembelajaran yang diselenggarakan. Maka” manajemen peserta didik" dapat dirumuskan sebagai penataan dan pengaturan terhadap kegiatan yang berkaitan dengan peserta didik mulai masuk sampai keluarnya pesrta didik tersebut dari suatu lembaga pendidikan (sekolah).

Kegiatan manajemen peserta didik merupakan bagian penting yang harus diperhatikan dalam penyelenggaraan kegiatan pendidikan di sekolah. Programprogram kegiatan manajemen kepeserta didikan yang diselenggarakan harus didasarkan kepada kepentingan dan perkembangan dan peningkatan kemampuan peserta didik dalam bidang kognitif, afektif dan psikomotor dan sesuai dengan keinginan, bakat dan minat peserta didik. Pengadaan program kegiatan manajemen kepeserta didikan diharapkan dapat menghasilkan keluaran yang bermutu.

Penyelenggaraan sekolah yang bermutu perlu didukung oleh ketersediaan layanan kepada peserta didik yang layak dan memadai dalam kuantitas maupun kualitasnya. Mengingat penyelenggaraan sekolah terus mengalami perubahan dan perkembangan, maka manajemen peserta didik yang ada di sekolah tersebut perlu melakukan inovasi yang sesuai dengan perubahan dan perkembangan yang ada, agar kegiatan manajemen peserta didik bisa mendukung keterlaksanaan program sekolah dan tercapainya tujuan pendidikan secara umum 


\section{Jurnal Serunai Administrasi Pendidikan \\ Vol.6, No.2, Juni 2018 \\ e-ISSN 2620-9209}

\section{DAFTAR PUSTAKA}

Adair, J. (1993) Membina Calon Pemimpin, terj. Soedjono Trimo. Jakarta: Bumi Aksara

Burhanuddin, (2004) Analisis Administrasi Manajemen. Bandung: Rosda karya

Daryanto. (2013) Administrasi Dan Manajemen Sekolah. Jakarta: Rineka Cipta

Mulysa, E. (2016) Menjadi Kepala Sekolah Profesional .Bandung: Rosda Karya

Saefullah. (2012) Manajemen Pendidikan Islam .Bandung: Pustaka Setia 